\title{
Hydropolitics of the Grand Ethiopian Renaissance Dam (GERD): Appraising the Socio-Economic and Security Implications
}

\author{
Sylvan Odidi", Rodgers Ombeck Oyoo** \\ ${ }^{*}$ Geopolitical Analyst \\ ** Department of Peace and Conflict Studies, Masinde Muliro University of Science \& Technology \\ DOI: 10.29322/IJSRP.11.10.2021.p11853 \\ http://dx.doi.org/10.29322/IJSRP.11.10.2021.p11853
}

\begin{abstract}
The Grand Ethiopian Renaissance Dam (GERD) conflict is the most current and deeply intense diplomatic crisis over the usage of the Nile waters. Over the last 30 years, the struggle for the Nile waters has and continues to develop significantly. In 2011, it worsen after Ethiopia began construction of the GERD project. The Nile Basin consisting of 11 countries that are of significant geopolitical interplay to the Nile's overall hydro-political regime. The aim of this research was to discuss the legal aspect of the GERD dispute, changing dynamics shaping the dispute as well as the socio-economic and security implications of GERD. This research is premised on secondary data in form of peer-reviewed journals, online newspapers, articles, relevant websites, and government documents. Analysis of relevant documents revealed that (1) The contradicting nature of treaties signed relating to the Nile River poses a major legal problem and is a source of misunderstanding between Egypt, Sudan, and Ethiopia with each country arguing the existing legal framework to promote their national interests (2) Population increase, climate change, regional supremacy battle as well as national pride play a key role in shaping the GERD dispute. (3) While the GERD project upon completion is projected to have vital positive implications such as cheap and affordable electricity to Ethiopia and her neighbours on one hand, it is considered to have the potential to result in negative effects which include; reduction of Sudan and Egypt water share as well as reduced capacity of electricity production of the dams in Sudan and Egypt particularly Aswan High Dam. The present dispute has also the potential of degenerating into wide instability in the Horn of Africa and therefore concerted effort of arriving at a balanced and fair agreement that takes care of the interests of not only three countries in dispute but also other upstream countries is crucial to this end.
\end{abstract}

Index Terms- GERD, Hydropolitics, Socio-economic and Security Implications

\section{INTRODUCTION}

$\mathrm{G}$ ERD project is presently being constructed on the upper part of Nile Basin. It is situated along River Nile (Blue) in Ethiopia, near Sudan's border area. Over the last 30 years, the struggle for the Nile waters has and continues to develop significantly. The GERD conflict worsen in 2011 when Ethiopia started its construction without any notification to Egypt and Sudan (Kandeel, 2020). GERD was over seventy percent complete as of August 2020 (Wheeler, Jeuland, Hall, Zagona, \& Whittington, 2020) and is projected to be completed in 2023. With an annual electricity generation capacity of 6000 megawatts, GERD is anticipated to be the leading hydropower project in the Africa Continent (Gebreluel, 2014).

There is a long history of the struggle of Nile River Waters between Ethiopia Sudan \& Egypt. In the 12th century, Amda Syon, the Ethiopian emperor threatened to change the flow of Nile waters if the Egyptian Sultan continued to persecute Coptic Christians (Pankhurst, 1997). Securing the constant movement of Nile waters therefore was and still is a matter of interest for Egyptians, and hence debatably the earliest and vital concern of the foreign policy of Egypt. (Gebreluel, 2014).

The GERD's reservoir can store $88 \%$ of the Nile River mean annual flow measured at Aswan and subsequently it is rational for Egypt and Sudan, to be alarmed. In addition, the GERD is being constructed at a point in which it has the ability to dam waters before the Nile river flows out of Ethiopian land, and therefore it can regulate a significant volume of Nile waters that reaches Sudan \& Egypt (Kandeel, 2020).

Owing to the Blue Nile's abundant prospective for electricity production as well as irrigation, Ethiopia asserts that its development is central to the country's socio-economic development. However, Ethiopia has sparingly utilized substantial shares of the water in the River Nile occasioned by its historical economic and political instability. In addition, Egypt, for a long time, had taken advantage of its economic strength, extensive diplomatic power as well as the inherent threat of force to deter dam construction financing (Seide \& Lind, 2013).

The Ethiopian government considers GERD as a source of cheap and affordable electricity and an opportunity for the country's development. However, the concern for Egypt and Sudan governments is that GERD will reduce their available water resources. On one hand, Ethiopia has been advocating for nonbinding rules on GERD filling as well as the operation process. While on the other hand, Egypt in together with Sudan is rooting for a permanent deal on filling and operation of the GERD as a way of conflict resolution.

Egypt significantly depends on Nile water for its freshwater needs. Approximately $90 \%$ of the water used in Egypt water 
emanates from the Nile, and almost $57 \%$ of that water flows from the Blue Nile out of which the GERD project intends to dam. The GERD reservoir, when filled, will contain about 74 BCM (Keith, 2020). The dispute between Egypt and Ethiopia has been referred to as toxic. Ethiopia, on one hand, has depicted Egypt as a neocolonial force striding on national sovereignty while Egypt on the other hand has blamed Ethiopia for cutting its main water supply with the intent of making Egypt waterless. (Konyn, 2020).

It is against this background of long-standing GERD conflict that this article aims at deliberating the legal aspect of the dispute, changing dynamics that continue to shape the dispute as well as socio-economic and security implications of GERD

\section{STUDY AREA}

The Nile Basin covers River Nile and 11 countries which include South Sudan, Kenya, Rwanda Burundi, Tanzania the DRC Congo, Sudan Egypt, Eritrea, Ethiopia, and Uganda as shown in figure 1 The vital sources of river Nile include (1) Blue Nile (2) White Nile (3) Atbara. The White and Blue Nile, which are major tributaries that merge in the capital city of Khartoum, Sudan to create the Main Nile. On one hand, the Blue Nile emanates from Lake Tana in Ethiopia while on the other hand, the White Nile emanates from Lake Victoria. The length of the Nile River is 6700 $\mathrm{km}$ (Abtew \& Dessu, 2019) and covers approximately 3.18 million square Kilometers of Eastern Africa (Mohamed, 2016). As of 2012, more than 400 million people were residing in the Nile Basin. It is estimated that this will rise to about 600 million by 2025 (Oestigaard, 2012).

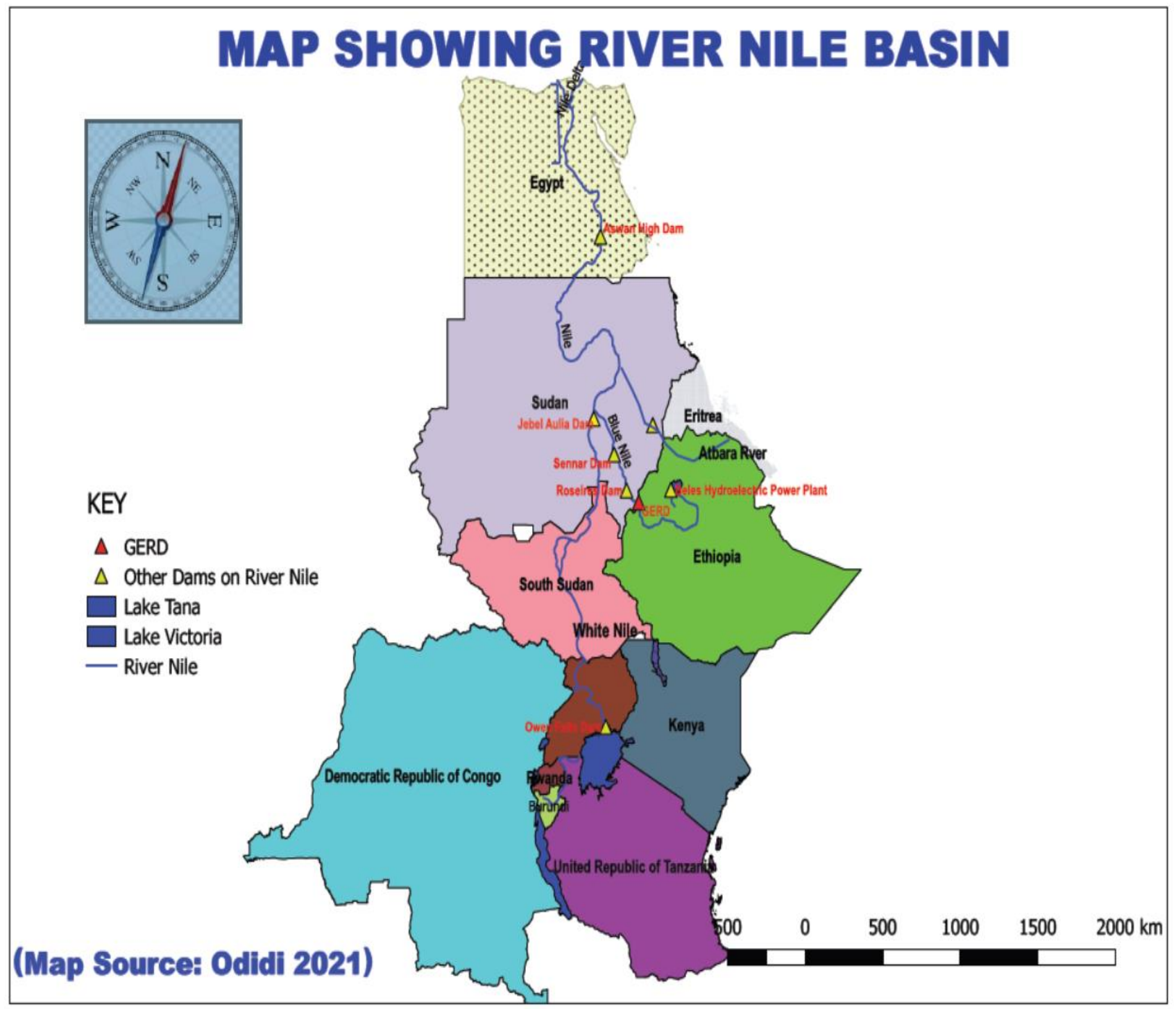

Figure 1: Showing River Nile Basin

\section{MATERIALS AND METHODS}

This study utilized desktop research method. It was premised on secondary data in form of peer-reviewed journals, online newspapers, articles, relevant websites, and government documents. 


\section{STUDY FINDINGS AND DISCUSSIONS}

\subsection{The Legal aspect of River Nile Dispute}

Egypt and Sudan have been basing their argument on the Anglo-Egyptian Treaty and Nile Waters Treaty as presented in Table 1, which provided them with exclusive Nile water rights that have been largely criticized by the upstream countries including Ethiopia who were not part of the agreements. The British rulers were driven by the strategic significance of Egypt to the British Empire. Egypt regulated access to the Suez Canal and consequently Britain's entry into the state of India (Di Nunzio, 2013). The upstream countries view the treaties as outdated. The autonomous action taken by Ethiopia to construct GERD characterizes a key political challenge to the Nile Water Treaty of 1959. It indicates that the exclusive power of Egypt in controlling the Nile has been fragmented, and confirms Ethiopia's political will of developing its water resources without an all-inclusive basin agreement (Gebreluel, 2014).

In addition; Sudan and Egypt make their case on their position with the Declaration of Principles of 2015 appended by the 3 countries as a reference document that provides the framework for the talks about the dams' first filling and yearly operation (El Tawil, 2020). For instance, Egypt and Sudan believe that Ethiopia violated the cooperation principle in the first filling of the dam under the Declaration of Principle of 2015 by initializing the process of filling the dam without notifying them. However, Ethiopia defended itself by arguing that the filling of the dam in July 2020 was part of a natural process due to the rise in frequency and intensity of rainfall events in the region.

Ethiopia, on the other hand, debates from the Cooperative Framework Agreement signed by the six downstream countries, Uganda, Tanzania, Burundi, Ethiopia, Uganda, and Kenya. The Cooperative Framework Agreement allowed for dam construction and undertaking of related projects which is contrary to colonial treaties. The contradicting nature of treaties signed relating to the Nile River poses a major legal problem and is a source of misunderstanding between Egypt, Sudan, and Ethiopia with each country arguing the existing legal framework to promote their national interests. The negotiations among countries in the Nile Basin have failed to formulate a broad-based legal regime. Different viewpoints of the Nile has been a major challenge, particularly between the upstream and downstream countries (Samaan, 2014).

Table 1: Historical Agreement $\&$ Treaties in the Nile Basin

\begin{tabular}{|c|c|c|c|}
\hline $\begin{array}{ll}\text { Treaties } & \text { and } \\
\text { Agreements } & \end{array}$ & Year & Parties involved & The outcome of the Agreements\& Treaties \\
\hline $\begin{array}{l}\text { Anglo-Italian } \\
\text { Treaty }\end{array}$ & 1898 & $\begin{array}{l}\text { Great Britain } \\
\text { Italy }\end{array}$ & $\begin{array}{l}\text { Britain acquired rights of preventing the } \\
\text { construction of dams along the Atbara River } \\
\text { (Samaan, 2014). }\end{array}$ \\
\hline $\begin{array}{l}\text { Anglo-Ethiopia } \\
\text { Treaty }\end{array}$ & 1902 & $\begin{array}{l}\text { Great Britain } \\
\text { Ethiopia }\end{array}$ & $\begin{array}{l}\text { Ethiopia agreed not to arrest or totally blocks } \\
\text { the flow of the Nile (Ullendorff, 1967). }\end{array}$ \\
\hline $\begin{array}{l}\text { Agreement between } \\
\text { Belgium and Great } \\
\text { Britain }\end{array}$ & 1906 & $\begin{array}{l}\text { Great Britain } \\
\text { Belgium }\end{array}$ & $\begin{array}{l}\text { Disallowed Congo from constructing projects } \\
\text { along Selmeki and Isango Rivers. } \\
\text { Allow water flow from Congo to the River Nile } \\
\text { (Samaan, 2014). }\end{array}$ \\
\hline $\begin{array}{l}\text { Anglo-Egyptian } \\
\text { Treaty }\end{array}$ & 1929 & $\begin{array}{l}\text { Egypt } \\
\text { Great Britain }\end{array}$ & $\begin{array}{l}\text { Egypt and Sudan were granted annual water } \\
\text { allocations of } 48 \text { BCM and } 4 \text { BCM } \\
\text { respectively. } \\
\text { Egypt maintained the right of monitoring water } \\
\text { on the Nile River in the upstream states. } \\
\text { Egypt got the right to stop any projects that } \\
\text { would interfere with her national interests } \\
\text { unfavorably. } \\
\text { Egypt obtained the right to embark on projects } \\
\text { on the River Nile without the consent of } \\
\text { upstream countries (Lumumba, 2007). }\end{array}$ \\
\hline Nile Water Treaty & 1959 & $\begin{array}{l}\text { Egypt } \\
\text { Sudan }\end{array}$ & $\begin{array}{l}\text { Amplified annual water allocation of Egypt to } \\
55.5 \mathrm{BCM} \\
\text { Increased Sudan's water allocation to } 18.5 \\
\text { BCM } \\
10 \mathrm{BCM} \text { was permitted for the evaporation } \\
\text { process and seepage (Chen \& Swain, 2014). }\end{array}$ \\
\hline $\begin{array}{l}\text { Nile Basin Initiative } \\
\text { Agreement }\end{array}$ & 1999 & $\begin{array}{l}\text { Kenya Egypt, Sudan, } \\
\text { Uganda } \quad \text { DRC, } \\
\text { Ethiopia, Burundi, } \\
\text { Rwanda, Tanzania }\end{array}$ & $\begin{array}{l}\text { Allowed development of the Nile River water } \\
\text { resources equitably and sustainably to } \\
\text { guarantee peace prosperity, security for all Nile } \\
\text { Basin population (Sileet, Abd El Fattah, \& } \\
\text { Soliman, 2007) }\end{array}$ \\
\hline
\end{tabular}




\begin{tabular}{|l|l|l|l|l|}
\hline $\begin{array}{l}\text { Cooperative } \\
\text { Framework } \\
\text { Agreement }\end{array}$ & 2010 & $\begin{array}{l}\text { Burundi Kenya } \\
\text { Rwanda Tanzania } \\
\text { Ethiopia Uganda }\end{array}$ & $\begin{array}{l}\text { Allowed the riparian countries to construct } \\
\text { dams and undertake related projects(Di Nunzio, } \\
2013)\end{array}$ \\
\hline $\begin{array}{l}\text { Declaration of } \\
\text { Principles } \\
\text { GERD. }\end{array}$ & 2015 & $\begin{array}{l}\text { Egypt, } \\
\text { Ethiopia } \\
\text { Sudan }\end{array}$ & $\begin{array}{l}\text { Provided the framework for the negotiations } \\
\text { regarding the dam's first filling and yearly } \\
\text { operation among other agreements (Tekuya, } \\
\text { 2020). }\end{array}$ \\
\hline
\end{tabular}

\subsection{The Changing Dynamics of the GERD Dispute.}

\section{Population increase}

The accelerated population growth in the states with the Nile Basin coupled with changing climate will place mounting demands on the Nile water resources. The population of Ethiopia, Sudan, and Egypt are projected to rise significantly in the near future. (Grafham, Soliman, \& Shamout, 2020). For instance, over the last fifty years, Egypt's population skyrocketed to 100 million from 35 million (Bearak \& Raghavan, 2020). According to Mohamed Abdel Ati, Egyptian Minister of Irrigation, the population of Egypt is projected to be 170 million in 2050 and consequently means Egypt will require not less than an extra 7.5 BCM of water to meets rising water needs (Youssef, 2020). This pushes Egypt to negotiate for an agreement to get significant water volume enough for its growing population. In addition, the growing development and energy needs of the Nile Basin counties will pile pressure over the Nile water resources which may further worsen the conflict.

\section{Climate change}

Climate change being experienced in Nile basin countries increases hydrometeorology events and hence has the potential to worsen the GERD dispute. For instance, in Egypt, climate change may lead to an increase in drought events and desertification, and therefore GERD construction on the Nile River will automatically worsen its water insecurity. However, in Ethiopia, the increase in frequency and intensity of flood events in recent times has led to a rise in water volume in GERD. This augered well with Ethiopia's plan to fill the dam within the shortest time possible. A case in point, Ethiopia attributed to the initial filling of the GERD with 4.9 BCM due to an increase in rainfall events. This was well evidenced by Satellite images released by European Space Agency. Pointedly, images captured by the Sentinel-1 satellite between June 27 and July 12, 2020, indicated a steady increase in the amount of water behind the GERD. (Cara, 2020) In addition, On July 15, 2020. Sudan reported that that the water levels of the Blue Nile river emanating from Ethiopia had b] dropped by 90 million cubic meters per day (Abdelaziz \& Awadalla, 2020).

This was widely celebrated by Ethiopians both at home and abroad but widely criticized by Egyptians. The greatest fear among Egyptians is that damming GERD to its full capacity may cause a serious water crisis and result in disruption of agricultural activities which is already evident. For instance, the shift from cotton to vegetable farming by Egypt's farmers has been occasioned by the reduced number of days of water supply by the Egyptian government due to national shortage (Youssef, 2020).

Climate change will severely alter water dynamics in the Nile Basin in the next century: researchers envisage that water demand will exceed supply by 2030. Since GERD's reservoir will be filled approximately within 7 years, dam project completion will coincide with this water shortage and subsequently will worsen tensions in the absence of a legal framework. The rapid pace of climate change makes it even more vital for Sudan, Ethiopia and Egypt, and Sudan to reach a fair and balanced agreement over Nile River waters (Cropper, 2020).

\section{Regional supremacy battle}

In the last 60 years, the Aswan High Dam has been an icon of hegemony of Egypt on the river and provided Egypt with tactical geopolitical advantage, water security and source of power, and GERD -upon completion will challenge the Aswan High Dam status quo (Dessu, 2019).

Egypt's Aswan High Dam (162 billion m3) has more than twice the volumetric capacity of the Renaissance Dam ( 75 billion $\mathrm{m} 3)$. The GERD project will be the second-largest dam in Africa by volume once completed. However, in terms of electricity production, the Renaissance Dam's 6,450MW rating will easily eclipse the Aswan High Dam's 2,100MW rating, making it the leading hydroelectric power plant in Africa (Aljazeera, 2020). For many years, Egypt has been able to uphold an influential stance in the Nile region. It has successfully utilized legal instruments to achieve compliance by Nile Basin states to the prevailing order. Moreover, the GERD construction will prove the quest for hegemony along the Nile basin. This is likely to increase the regional influence of Ethiopia while diminishing Egypt's. The hegemonic shift in the Nile Basin is plausible and seems inevitable. Hence the war waged by Egypt against GERD goes beyond the control of Nile waters to forment regional supremacy wars.

\section{National pride}

Ethiopia has publicized the GERD project as an exceptionally vital development project, referred to as a "strategically important initiative" and has prohibited global financial assistance, a pointer to the stature of the project as an emblem of national pride. GERD, therefore, is partially financed by Ethiopians, largely via wage "donations" and collection of tax. Ethiopian government public servants contribute a portion of their salary to the GERD project, considered "a national project."(Hicks, 2017 ) Therefore, Ethiopia considers GERD an epitome of sovereignty and national pride while Egypt on the other hand views the dam as a national security issue due to expected negative consequences. Egypt depends on River Nile for its $90 \%$ freshwater needs and therefore views the dam project as an existential threat, as it fears the dam will impact negatively its water supplies.

\subsection{Socio-economic and security implications of GERD}

Analysis of relevant literature reveals that GERD has both potential benefits and risks. This section discusses socioeconomic and security implications for Sudan, Ethiopia, Egypt, and other downstream states within the Nile Basin. 


\section{Ethiopia}

GERD construction in Ethiopia is driven by the need for enhanced electrification, accelerated industrialization, and prospective sales of electricity to neighboring countries. Ethiopia has inadequate petroleum and mineral resources but poses great potential for hydropower power production, of approximately $45,000 \mathrm{GW}$. Therefore it can export electricity to countries within the Eastern African region. Upon completion, GERD aims to generate approximately 6,000 MW of electricity for export and domestic use. This would enable the country to mitigate abject poverty levels and achieve sustainable development goals (Lashitew \& Kassa, 2020). The electricity capacity of Ethiopia is 3,200 MW however her yearly per capita electricity consumption is rated amid the bottommost globally- 65 kilowatt-hours in 2013, way below the normal of $488 \mathrm{kWh}$ for sub-Saharan African states and the global mean of $3,104 \mathrm{kWh}$ (Kimagai, 2016). This is only adequate for approximately $30 \%$ of its citizens' needs and consequently; seventy percent of the 110,000 million people are not sufficiently connected to the grid. In addition, the majority of the Ethiopian people live in rural areas where access to electricity is limited. The rural communities largely rely on traditional biomass energy sources such as wood (Hailu \& Kumsa, 2021). Therefore, the GERD project would cater to the acute energy shortage that is accelerating yearly.

Secondly, the dam project will be a power hub for states within the Nile Basin. According to World Bank data of 2018, Africa produces $4 \%$ of global electricity out of which $75 \%$ of its total electricity is utilized by Egypt, North Africa coast countries as well as South Africa (Tesfa, 2021). Ethiopia will be able to trade extra electricity produced to South Sudan, Kenya among others. This represents a vital source of income (Woldetatyos, 2020). It is estimated by the World Bank that Ethiopia can receive $\$ 1$ billion yearly from the export of electricity and thus making it the leading exporter of hydropower in Africa (Kimagai, 2016). Returns from the exports will lessen pressing economic problems such as the national debt crisis as well as the scarcity of foreign currency. The hydropower project will reduce revenue losses experienced by businesses in East Africa occasioned by constant electric power interruption. Out of the three countries involved in the negotiation of the GERD dispute, the losses experienced by Ethiopia is the highest at $6.9 \%$. Decreasing the loss by $50 \%$ would lead to substantial economic gains potentially contributing to the creation of job opportunities, higher productivity as well as export performance. Consequently, optimum utilization of the GERD, therefore, has the capability of enhancing economic development in Eastern African. (Lashitew \& Kassa, 2020). Ethiopian Investment Commission opines that GERD will provide about 5,700 overseas enterprises utilizes with power, most particularly the expanding industrial hub that expands to the Adama from Ethiopian Capital. This will in turn spur Ethiopia's industrial development (Bearak \& Raghavan, 2020). The ongoing GERD project construction works and the power grid are providing new business investments and employment prospects. The construction work of the dam is anticipated to generate 12,000 jobs opportunities (Woldetatyos, 2020). This is likely to improve the living standards of Ethiopians. GERD will also play a significant role in water conservation due to the lower evaporation rate in Ethiopia Highland (El-Nashar \& Elyamany, 2018).

However, despite all the potential benefits of GERD, the dam also brings along associated risks. For instance, environmental-based groups have contended that the dam has the likelihood of flooding $1,680 \mathrm{sq} \mathrm{Km}$ of forest land as well as displace around twenty thousand people in Gambela, Somali, Afar, and BenishangulGumuz in Ethiopia (Agencies, 2020).

\section{Egypt}

The independent development of the Nile River by upper riparian states more specifically Ethiopia without any negotiated management deal has the probability of having unfavorable consequences on Egypt's state and her freshwater capacity. A case in point is the construction of GERD. Egypt -a water-scarce nation -worries that the 55.5 BCM of water volume allocated to her by the Nile Water Treaty of 1959 will be impacted negatively when GERD is completed and begins the process of filling and operation. The Northern Africa state is majorly concerned about GERD because of its substantial reliance on the River Nile, which provides $90 \%$ of its freshwater. As its population rises unsustainably-nearly $2 \%$ per year-water needs of Egypt by far dwarf its usage and access to Nile waters and as a result, Egypt considers GERD as a potential threat to its water sources. Undoubtedly, filling GERD reservoirs up to approximately 74 BCM will diminish its present share of the Nile River water. (Halawa, 2018).

Mahmoud (2016) reveals that Egypt requires roughly 120 BCM of water yearly. Other than water from the Nile, Egypt obtains additional 20.5 BCM meters from groundwater as well as recycled agricultural drainage water and treated wastewater. These figures reveal a grave water shortage in Egypt. Consequently, the construction of the dam raises doubts of water inadequacy as wells as drought. (Mahmoud, 2016)

Analyses of five scenarios being negotiated by Egypt, Sudan, and Ethiopia indicate that filling of GERD will significantly affect water availability and agricultural land in Egypt as indicated in table 2. The scenarios below are based on academic research; highlight the potential impact on Egypt's agricultural land and its water reserves subject to how swiftly Ethiopia fills the dam reservoir. The time covered in filling GERD influences how much water will make it downstream into Egypt. The shorter the time, the lower the flow. The water deficit is expected to increase by a higher volume in Egypt if Ethiopia fills the GERD within a short period. Egypt's agricultural land could potentially be lost to drought and desertification when Ethiopia fills the dam within the shortest period. For instance, if it takes three years to fill the dam, $67 \%$ of the land could be lost in Egypt. However, only $2.5 \%$ of Egypt's agricultural land will be lost when Ethiopia fills the dam in 21 years as indicated in scenario one (Aljazeera, 2020)

\section{Table 2: Impact of GERD water availability and agricultural land in Egypt}

\begin{tabular}{|l|l|l|l|}
\hline Scenarios & Time Taken to fill GERD & $\begin{array}{l}\text { The volume of expected } \\
\text { water deficit to increase }\end{array}$ & $\begin{array}{l}\text { Percentage of Agricultural land that } \\
\text { could be lost in Egypt. }\end{array}$ \\
\hline
\end{tabular}

This publication is licensed under Creative Commons Attribution CC BY.

http://dx.doi.org/10.29322/IJSRP.11.10.2021.p11853

Www.ijsrp.org 


\begin{tabular}{|l|l|l|l|}
\hline & \multicolumn{1}{|c|}{$\begin{array}{l}\text { on annual basis in Egypt } \\
\text { in (BCM) }\end{array}$} & \\
\hline Scenario 1 & 21 years & $3 \mathrm{BCM}$ & $2.5 \%$ \\
\hline Scenario 2 & 10 years & $8 \mathrm{BCM}$ & $18 \%$ \\
\hline Scenario 3 & 7 years & $12 \mathrm{BCM}$ & $30 \%$ \\
\hline Scenario 4 & 5 years & $20 \mathrm{BCM}$ & $50 \%$ \\
\hline Scenario 5 & 3 years & $27 \mathrm{BCM}$ & $67 \%$ \\
\hline
\end{tabular}

On the other hand, if the filling process were to be prolonged to above 12 years, Ethiopia would have a substantial economic cost. At a charge of approximately 7 cents per KW hour, the yearly revenue from the hydropower produced by the GERD at full capacity will be nearly $\$ 1$ bn. (Lashitew \& Kassa, 2020).

The operation of the Aswan High Dam will also be significantly affected by GERD's filling and operation process. Additionally, Egypt could experience severe water shortages if there is no proper coordination of GERD operation with Aswan High Dam after the finalization of the GERD project. (Whittington, Waterbury, \& Jeuland, 2014). Subsequently, GERD filling and operation will significantly affect agricultural activities in Egypt due to reduced water availability. For instance, River Nile serves as an important source of water for irrigation in Kom Hamada, the Delta region in Egypt. There has been immense reduction of water levels in Kom Hamada and Egyptian farmers are worried that livelihood will be significantly affected by the GERD project. Acute water shortages occasioned by population increase as well climate change have changed their life heritage rice cultivation. As a pointer, two years ago, Egypt decrease rice production lands by over $50 \%$ from $1.76 \mathrm{~m}$ to 750,000 acres to preserve 3 BCM of water volume (Bearak \& Raghavan, 2020).

Even though Egypt state is set to benefit from GERD in terms of water conservation, reduced siltation, and hydroelectric power it still considers GERD as an existential threat to its water resources. Egypt has warned that filling the reservoir will heighten tensions and could provoke disruptive regional conflict.

\section{Sudan}

Sudan is the other player in this regional water theater: caught between the opposing interests of Ethiopia and Egypt. There are potential risks and opportunities for Sudan. From a risk perspective, the filling of the GERD characterizes a threat to the national security of Sudan. The filling of the GERD reservoir has compromised the electricity production capacity of Roseires and Merowe Dams in Sudan, as well as endangered the safety of approximately 20 million Sudan nationals residing downstream of the GERD project. (Abdelaziz, 2021).

However, despite these risks, there are potential benefits that Sudan is likely to accrue. They include and are not limited to the availability of cheap and affordable electricity, flood control, reduced siltation, and increased irrigated agriculture. Unparalleled flooding in Sudan in 2020 resulted in 100 fatalities and significantly affected about 875,000 people. It is argued that GERD will play a very significant role to control flooding that currently affects Sudan (BBC, 2020). The dam can handle a 19,370 m3 per second flood, diminish alluvium by 100 million $\mathrm{m} 3$ as well as to irrigate approximately 500,000ha of new agricultural in Sudan. (Construction Review Online, 2021).

\section{CONCLUSION}

This paper has demonstrated that GERD construction presents an opportune moment for Sudan, Ethiopia, and Egypt to cooperate in transboundary water governance. While the prospective gains of GERD to the three countries are clear, the focus on how GERD will affect power generation and water supply in Sudan and Egypt during its filling and operation still elicits varied opinions and is the focus of ongoing debates. GERD will undoubtedly cause environmental, social, and economic change. This dispute has the potential to cause regional instability if it is not resolved. Egypt, Ethiopia, and Sudan should prioritize cooperation to find an amicable solution that serves the interest of not only the three countries but also other countries within the Nile basin.

In addition, it is worth noting that Ethiopia has an alienable right of exploiting her internal water assets to spur socio-economic development but not to the expense of downstream states and therefore it should also take into consideration how best to mitigate the possible negative implications of the GERD project to Egypt and Sudan.

\section{RECOMMENDATIONS}

i. Nile Basin countries should intensify collaboration and detailed studies in GERD management in order to filter concrete paybacks that could improve the standard of living of all people in the Nile Basin region.

ii. Sudan, Egypt, and Sudan should capitalize on dialogue in assessing probable risk and propose carefully thought out policies of that cover filling, operations, and sediment management.

iii. Cooperation between Egypt, Sudan, and Ethiopia is not an option but a matter of necessity in exploring, accessing, and formulating different scenarios on dam implication on environmental, political, social, economic, cultural sectors at both local and regional levels. This is to prevent the escalation of conflict that can result in war and consequently destabilize the region.

iv. The Nile basin countries should invest in strategic water resource planning and management that guarantees compromised benefits not only to the downstream 
countries (Sudan \&Egypt) but also to the other upstream countries.

v. Sudan, Egypt, and Ethiopia should invest in in-depth research studies on potential earthquakes and landslides which might be triggered by GERD, and structural mitigation measures should be developed and implemented to prevent potential negative impacts

vi. Egypt should invest in alternative water resources such as groundwater reserves. In addition, the farmers in Egypt should invest in water-resistant crops because they are likely to be affected most once the dam is operational.

\section{ACKNOWLEDGEMENT}

The researchers sincerely appreciate all individuals who contributed significantly to the success of this paper

\section{REFERENCES}

[1] Abdelaziz, K. (2021). Filling Ethiopia's Renaissance Dam in July threatens Sudan's security - minister Reuters Retrieved from https://www.reuters.com/article/us-ethiopia-dam-sudan-idUSKBN2A60P3.

[2] Abdelaziz, K \& Awadalla, N. 2020 Sudan says Nile water levels fall after Ethiopia starts giant dam Reuters Retrieved from https://www.reuters.com/article/us-ethiopia-dam-sudan-idUSKCN24G2CS.

[3] Abtew, W., \& Dessu, S. B. (2019). The Grand Ethiopian Renaissance Dam on the Blue Nile: Springer.

[4] Aljazeera. (2020). Saving the Nile Retrieved fromhttps://interactive.aljazeera.com/aje/2020/saving-the-nile/index.html.

[5] Agencies, (2020) Ethiopian Renaissance Dam Controversy: Egypt And Sudan For More Negotiations On Flow of Water In Nile Spotlight Retrieved from https://www.spotlightnepal.com/2020/07/22/ethiopian-renaissancedam-controversy-egypt-and-sudan-more-negotiations-flow-water-nile/.

[6] BBC. (2020). How the controversial Nile dam might fix Sudan's floods. Retrieved from https://www.bbc.com/news/world-africa-54748204.

[7] Bearak, M., \& Raghavan, S. (2020). Africa's largest dam powers dream of prosperity in Ethiopia - and fears of hunger in Egypt Washington Post Retrieved from https://www.washingtonpost.com/world/interactive/2020/grand-ethiopianrenaissance-dam-egypt-nile/.

[8] Cara A, Satellite images show Ethiopia dam reservoir swelling, Associated Press, (Jul. 14, 2020), Retrieved from https://apnews.com/600710323bb9bb4427a3d3b9a3115bae

[9] Chen, H., \& Swain, A. (2014). The Grand Ethiopian Renaissance Dam: Evaluating its sustainability standard and geopolitical significance. Energy Development Frontier, 3(1), 11.

[10] Construction Review Online. (2021). A look at Africa's largest dams. Retrieved from https://constructionreviewonline.com/biggestprojects/africas-largest-dams/

[11] Cropper, L. L. a. N. (2020). The Ebbs and Flows of the Renaissance Dam Dispute Retrieved from https://www.americansecurityproject.org/the-ebbsand-flows-of-the-renaissance-dam-dispute/

[12] Dessu, S. (2019). The Grand Ethiopian Renaissance Dam is a new reality. Why a deal must be done The Coversation Retrieved from https://theconversation.com/the-grand-ethiopian-renaissance-dam-is-thenew-reality-why-a-deal-must-be-done- 107100

[13] Di Nunzio, J. (2013). Conflict on the Nile: The future of transboundary water disputes over the world's longest river. Future Directions International Strategic Analysis Paper, Dalkeith.

[14] El-Nashar, W. Y., \& Elyamany, A. H. (2018). Managing risks of the Grand Ethiopian renaissance dam on Egypt. Ain Shams Engineering Journal, 9(4), 2383-2388.

[15] Eldardiry, H., \& Hossain, F. (2021). Evaluating the hydropower potential of the Grand Ethiopian Renaissance Dam. Journal of Renewable and Sustainable Energy, 13(2), 024501.
[16] ElTawil, N. (2020). Declaration of Principles on Renaissance Dam is 'exclusive agreement' binding Egypt, Ethiopia, Sudan together: intl. law expert. Egypt Today Retrieved from https://www.egypttoday.com/Article/1/88909/Declaration-of-Principles-onRenaissance-Dam-is-exclusive-agreement-binding

[17] Gebreluel, G. (2014). Ethiopia's Grand Renaissance Dam: ending Africa's oldest geopolitical rivalry? The Washington Quarterly, 37(2), 25-37.

[18] Grafham, O., Soliman, A., \& Shamout, N. (2020). Nile Basin States must persist with Water Diplomacy Chatam House. Retrieved fromhttps://www.chathamhouse.org/2020/08/nile-basin-states-must-persistwater-diplomacy.

[19] Hailu, A. D., \& Kumsa, D. K. (2021). Ethiopia renewable energy potentials and current state [J]. AIMS Energy, 9(1), 1-14.

[20] Halawa, H. (2018). Egypt's options in the development of the Ethiopian dam Atlantic Council Retrieved from https://www.atlanticcouncil.org/blogs/menasource/egypt-s-options-in-thedevelopment-of-the-ethiopian-dam/

[21] Hicks, S. (2017). The Grand Ethiopian Renaissance Dam: Power Dynamics in the Nile River Basin Retrieved from https://www.americansecurityproject.org/the-grand-ethiopian-renaissancedam-power-dynamics-in-the-nile-river-basin/

[22] Kandeel, A. (2020). Nile Basin's GERD dispute creates risks for Egypt, Sudan, and beyond Retrieved from https://www.atlanticcouncil.org/blogs/menasource/nile-basins-gerd-disputecreates-risks-for-egypt-sudan-and-beyond/

[23] Kansara, P., Li, W., El-Askary, H., Lakshmi, V., Piechota, T., Struppa, D., \& Sayed, M. A. (2021). An assessment of the filling process of the Grand Ethiopian Renaissance Dam and its impact on the downstream countries. Remote Sensing, 13(4), 711.

[24] Keith, J. (2020). Egypt and Ethiopia Said to Be Close to Accord on Renaissance Foreign Policy Retrieved from https://foreignpolicy.com/2020/01/16/egypt-ethiopia-gerd-talksrenaissance-dam-accord/.

[25] Kimagai, J. (2016). The Grand Ethiopian renaissance dam gets set to open. IEEE spectrum. https://spectrum. ieee. org/energy/policy/the-grandethiopian-renaissance-dam-gets-set-to-open.

[26] Konyn, C. (2020). Tensions in Africa Amid Development of Ethiopian Hydroelectric Dam Retrieved from https://earth.org/tensions-in-africa-amiddevelopment-of-grand-ethiopian-renaissance-dam/.

[27] Lashitew, A., \& Kassa, H. (2020). Of regional destabilization How can the friction between Egypt and Ethiopia over the GERD be resolved? Africa Business Retrieved from https://african.business/2020/05/economy/ethiopias-blue-nile-dam-is-anopportunity-for-regional-collaboration/.

[28] Lumumba, P. L. O. (2007). The Interpretation of the 1929 Treaty and its Legal Relevance and Implications for the Stability of the Region. African Sociological Review/Revue Africaine de Sociologie, 11(1).

[29] Mahmoud, M. (2016). Egypt and Ethiopia: Fears of Drought and Dreams of Development Atlantic Council Retrieved fromhttps://www.atlanticcouncil.org/blogs/menasource/egypt-and-ethiopiafears-of-drought-and-dreams-of-development/.

[30] Mohamed, N. N. (2016). Nile River Biography and its Journey from Origin to End The Nile River (pp. 1-32): Springer.

[31] Oestigaard, T. (2012). Water scarcity and food security along the Nile: politics, population increase, and climate change: Nordiska Afrikainstitutet.

[32] Pankhurst, R. (1997). The Ethiopian Borderlands: Essays in regional history from ancient times to the end of the 18th century: The Red Sea Press.

[33] Reuters, Sudan says Nile water levels fall after Ethiopia starts giant dam, (Jul. $15,2020,11: 52$ AM), https://www.reuters.com/article/ethiopia-damsudan/sudan-says-nile-water-levels-fall-after-ethiopia-starts-giant-damidUSC6N2CH02H.

[34] Samaan, M. M. (2014). The Win-win-win Scenario in the Blue Nile's Hydropolitical Game: Application on the Grand Ethiopian Renaissance Dam: Inst. für Sozialwiss.

[35] Seide, W. M., \& Lind, J. (2013). Churning Waters: Strategic Shifts in the Nile Basin.

[36] Sileet, T., Abd El Fattah, M., \& Soliman, W. (2007). Impact of the Nile Basin Initiative on the Agricultural Policy of Egypt, conference paper, water demand management in the Mediterranean progress and policies. Zaragoza. 
[37] Swain, A. (2020). Grand Ethiopian Renaissance Dam: Catalyst for basinwide water cooperation ? Africa Report Retrieved from https://www.theafricareport.com/35797/grand-ethiopian-renaissance-damcatalyst-for-basin-wide-water-cooperation/

[38] Tekuya, M. (2020). The Grand Renaissance Dam: what's at stake and what could break the deadlock. The Conversation Retrieved from https://theconversation.com/the-grand-renaissance-dam-whats-at-stake-andwhat-could-break-the-deadlock-143018.

[39] Tesfa, B. (2021). Ethiopian Dam: Blessing for Nile Basin countries Daily Monitor Retrieved from https://www.monitor.co.ug/uganda/specialreports/ethiopian-dam-blessing-for-nile-basin-countries-3367816.

[40] Ullendorff, E. (1967). The Anglo-Ethiopian Treaty of 1902. Bulletin of the School of Oriental and African Studies, University of London, 641-654.

[41] Wheeler, K. G., Jeuland, M., Hall, J. W., Zagona, E., \& Whittington, D. (2020). Understanding and managing new risks on the Nile with the Grand Ethiopian Renaissance Dam. Nature communications, 11(1), 1-9.

[42] Whittington, D., Waterbury, J., \& Jeuland, M. (2014). The Grand Renaissance Dam and prospects for cooperation on the Eastern Nile.

\section{AUTHORS}

First Author - Sylvan Odidi, Geopolitical Analyst, odidisylvan@gmail.com

Second Author - Rodgers Ombeck Oyoo, Department of Peace and Conflict Studies, Masinde Muliro University of Science and Technology, rombeck93@gmail.com

Correspondence Author - Sylvan Odidi, Geopolitical Analyst, odidisylvan@gmail.com 